Revista de Biología Marina y Oceanografía

Vol. 48, №3: 553-563, diciembre 2013

DOI 10.4067/S0718-19572013000300012

Article

\title{
Fish assemblage structure in relation to environmental conditions in a tropical estuary
}

Ensamblaje estructural de peces en relación a las condiciones ambientales en un estuario tropical

\begin{abstract}
Alicia González-Solis ${ }^{1}$ and Daniel Torruco ${ }^{1}$
${ }^{1}$ Centro de Investigación y Estudios Avanzados del Instituto Politécnico Nacional, Unidad Mérida, Km. 6 Antigua Carretera a Progreso, A.P. 73 CORDEMEX, Mérida, Yucatán, México.dantor6660@gmail.com

Resumen.- La estructura de la comunidad de peces del estero de Sabancuy, México, fue analizada durante 2 temporadas climáticas usando datos de abundancia, biomasa y de 14 parámetros ambientales. No se encontraron diferencias estadísticamente significativas entre los datos obtenidos en las 2 estaciones climáticas. En el estuario se definieron 2 zonas ambientales, una que se extiende desde el sureste hasta el puente de Sabancuy y la otra desde ese sitio hasta la cabeza del estuario. Se registraron un total de 32 especies de peces representando a 21 familias. Las familias más abundantes fueron: Gerridae, Sciaenidae, Sparidae, Lutjanidae y Ciprinodontidae. La diversidad fue alta en el centro de la laguna. La clasificación comunitaria dió como resultado 3 ensamblajes con diferencias notables en la distribución espacial. Una muestra la influencia de la comunicación del estuario con la laguna de Términos, la segunda muestra la cabeza del estuario y la tercera una zona transicional cerca del puente que divide al estuario. La organización ecológica del estuario estuvo dividida en 2 áreas por el puente, con relativa escasez de hábitats y alimento y una consecuente pobreza de especies en los 2 extremos. La concentración de fosfato tiene la mayor influencia en el ensamblaje de la comunidad de peces.
\end{abstract}

Palabras clave: Ensamble de peces, distribución espacial, diversidad, estuario tropical, México

\begin{abstract}
Fish community in Sabancuy Estuary, Mexico, was analyzed during 2 a dry and a rainy seasons using 14 environmental parameters and fish species abundance and biomass data. No significant differences in data were observed between seasons. Two environmental zones were defined within the estuary, one extending southwest from a bridge and the other northeast from the bridge to the estuary head. A total of 21 fish families and 32 species were recorded. The most abundant families were Gerridae, Sciaenidae, Sparidae, Lutjanidae and Ciprinodontidae. Diversity was high in the central lagoon. Fish community classification resulted in 3 assemblages with notable differences in spatial distribution. One was influenced by estuary communication with Terminos Lagoon, a second was at the estuary head and a third at the transitional zone near the bridge dividing the estuary. Ecological organization of the Estuary was divided into 2 areas by the bridge, with relative habitat and food resource scarcity and consequent species paucity at the 2 extremes. Phosphate concentrations had the most influence on fish community assemblage.
\end{abstract}

Key words: Fish assemblage, spatial distribution, diversity, tropical estuary, Mexico

\section{INTRODUCTION}

Rapid and continuous growth of human settlements on coasts has led to important changes in coastal region physics, chemistry and biology (Vitousek et al. 1997). Geomorphological and chemical studies have been done of the principal coastal lagoons in Mexico (Graham et al. 1981, Day et al. 1982, Contreras 1993). Despite this, very little is known about the intensity of the environmentalbiological relationships in these bodies of water, although most are subject to some level of exploitation.

The main body of Terminos Lagoon, in the southwest Yucatan Peninsula, has received intense study (Purcell 1974, Mancilla \& Vargas 1980, Escanero 1983), but data for many of the adjacent estuaries is inconsistent and scarce. This hampers development of coastal resource management plans, which are essential to establishing the programs and policies required to support sustainable development in the region. To better understand lagoon and estuary dynamics, multiple research strategies are needed that identify water quality parameters, which offer a highly-detailed, up-to-date perspective of the influence these factors have on estuarine biota; as well as any limits or gradients that may exhibit variations in scale, space and time (Margalef 1993). Some of these data are generated in a regular and predictable approach, while others occur 
at unpredictable and random intervals (Pollard 1994). The present study objective was to analyze fish community structure and its relationship to the environment in Sabancuy Estuary in an attempt to understand the processes that determine its fish distribution and abundance and thus improve resource management practices (Yañez-Arancibia et. al 1988). Describing Sabancuy Estuary environmental conditions and analyzing the variables that affect its fish abundance and biomass is essential to creating management plans that acknowledge local use practices while promoting sustainable use.

\section{Materials ANd Methods}

\section{STUdy AREA}

Sabancuy Estuary is located in Campeche State, Mexico, in the southeast Yucatan Peninsula (Fig. 1). Mean annual temperature in the region is $26^{\circ} \mathrm{C}$, and average annual rainfall is $1027-1210 \mathrm{~mm}$, with heavy summer rains. Considered part of the southwest Campeche flood plain, the estuary communicates with the northeast portion of the Terminos Lagoon complex. Lagoon hydrology consists of numerous flooded lowlands with high soluble salts content, as well as lagoons and wetlands, all below 10 m altitude (Carranza-Edwards et al. 1975). The estuary

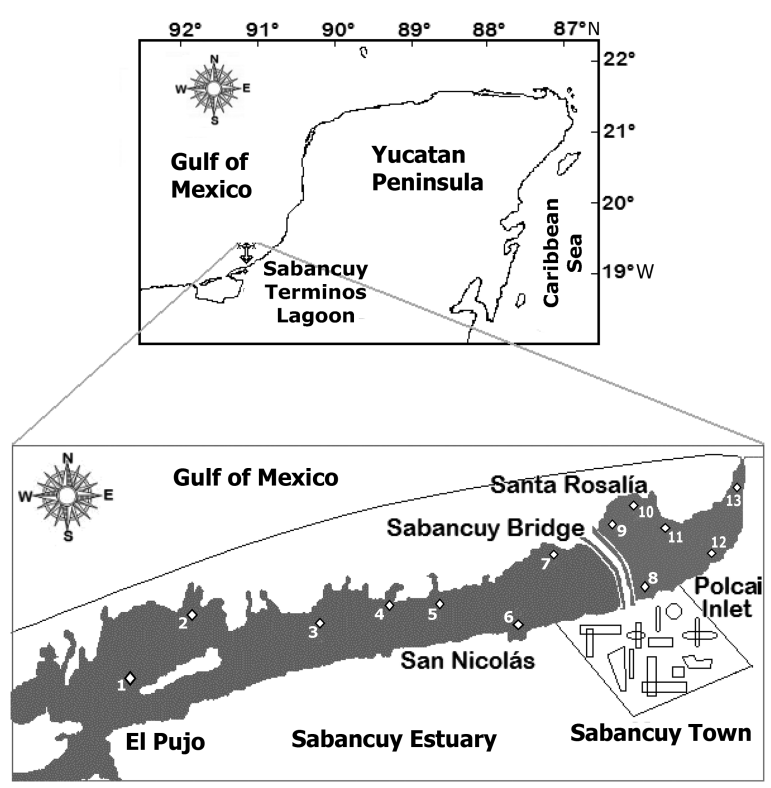

Figure 1. Location of the Sabancuy Estuary and sampling sites position / Localización del estuario de Sabancuy y posición de los sitios de muestreo connects to Terminos Lagoon via a canal running southwest and directly to the sea through an inlet in its central portion.

\section{SAMPLING}

Sampling was done at the end of the regional dry season (16 to 25 March 2009) and the beginning of the rainy season (1 to 10 July 2009). Thirteen sampling stations were established along the length of the estuary: 3 in the southwest; 4 in the center; and 6 in the northeast (Fig. 1). Environmental and water quality parameters were measured at half the water column depth at each station. Following Grasshoff (1983) and Strickland \& Parsons (1972), data were collected for ammonium, nitrite, nitrate, phosphate and silicate. Ammonium was measured by adding indophenol blue compound and reading absorbance in a spectrophotometer. Nitrite was quantified by a reaction with sulfanilamide and $\mathrm{N}$-naphthyl in an acid medium to form diazo dye, and absorbance read in a spectrophotometer. Nitrate was first reduced to nitrite in a cadmium-copper column and then analyzed as nitrite. Phosphate was measured by forming a complex with molybdate in an acid medium, reducing it with ascorbic acid and measuring absorbance in a spectrophotometer. Silicate was quantified by reacting the sample with molybdic acid and then with methylsulfite reducing agent to form a blue complex, and measuring absorbance in a spectrophotometer (Spectro UVS-2800, Labomed, Inc.).

Temperature, salinity, oxygen and oxygen saturation were measured with a multiparameter Sondes YSI-600. A sediment core ( $10 \mathrm{~cm}$ diameter $\mathrm{x} 20 \mathrm{~cm}$ long) was taken to measure granulometry and organic material content. Grain size analysis was done by sieving and pipetting according to Folk (1974). Samples were placed in a vertical agitation rot-tap with a set of sieves [U.S. standard with $1 / 2$ intervals phi $(\phi)]$ and sifted for $20 \mathrm{~min}$ to fractionate the sediment. The fine fraction was analyzed using a $15 \mathrm{~g}$. sample and the Bouyoucos technique, based on silt and clay sedimentation at different times using the Stokes law; total percentages were determined based on the differences in the hydrometer. Organic matter content was measured following Dean (1974), based on weight loss in a $5 \mathrm{~g}$ sample after ignition in a muffle furnace.

Fish samples were taken using 1.5-inch mesh trawl nets for $15 \mathrm{~min}$ at each station. All collected specimens were fixed with $10 \%$ formalin and then transported to the laboratory for identification, counting and weighing. 


\section{Statistical analysis}

Univariant statistical comparison t-tests were run for each sampling data set to determine significant difference. No differences were identified (t-test; $P=0.001$ ), so both sets were averaged to form a single matrix.

Different indices were used to identify fish community structure: Dominance was calculated with an importance value index (IVI) that includes frequency, numerical abundance and species biomass. A Simpson diversity index was used to identify different categories and their relative significance in the community (Galluci 1973).

$$
D=\frac{\sum_{i=1}^{S} \quad n_{i}\left(n_{i}-1\right)}{N(N-1)}
$$

where: $\mathrm{N}=$ Total number of organisms of all species; and $\mathrm{n}=$ Total number of organisms of a particular species.

To complement the community patterns description, which differed in both scale and intensity, a Morisita index was applied to determine site affinity in terms of numerical abundance and biomass (Orloci 1978, Pielou 1984)

$$
C_{D}=\frac{2 \sum_{i=1}^{S} x_{i} y_{i}}{\left(D_{x}+D_{y}\right) X Y}
$$

where: $x_{i}$ is the number of times species $i$ is represented in the total $X$ from one sample; $y_{i}$ is the number of times species $i$ is represented in the total $Y$ from another sample; $D_{x}$ and $D_{y}$ are the Simpson's index values for the $x$ and $y$ samples respectively; and $S$ is the number of unique species.

A canonical analysis was then run with the environmental, species and station data to define the relationships between them. The selected canonical analysis was direct gradient analysis, where the model assumes a linear response between the fish data and the environmental elements. The statistical significance of each variable's effect was tested with a Monte Carlo permutation test (999 random permutations). The Monte Carlo test does not require an assumption of normality and was therefore used instead of the F or t-test in multiple regression forward selection.

\section{Results}

Two hydrological zones were defined within the Sabancuy estuary. The largest area extends from the bridge connecting the town of Sabancuy to the sand barrier island southwest to the estuary's opening into Terminos Lagoon. The smaller area extends northeast from the bridge to the estuary head.

The lagoon is generally very shallow with depths of less than $1 \mathrm{~m}$ in the northeast to slightly deeper than $2 \mathrm{~m}$ in the southwest and central channels. The area in the southwest estuary known as El Pujo is extremely shallow, has limited water circulation and is slowly filling with sediment (Fig. 2a). Salinity was maintained at low levels by freshwater run-off from the surrounding flood zone (Fig. 2b). Dissolved oxygen content was normal (3.1 to $4.8 \mathrm{ml} \mathrm{l}^{-1}$ ) throughout the lagoon (Fig. 2c). The highest concentration $\left(4.8 \mathrm{ml} \mathrm{l}^{-1}\right)$ was recorded adjacent the Polcai sea inlet, which was oversaturated (102-108\%; Fig. 2d). Water temperature varied little throughout the estuary (29 to $32^{\circ} \mathrm{C}$ ). Due to shallow depth and high solar exposure, the southwest estuary had the highest temperatures (Fig. 2e). Ammonium concentration was generally high, with the highest values $\left(40 \mathrm{mg}\right.$-at $\left.\mathrm{N}^{-1}\right)$ in El Pujo, the lowest (14.9 mg-at $\mathrm{N}^{-1}$ ) near the bridge, and values increasing to $27.4 \mathrm{mg}_{\text {-at }} \mathrm{N}^{-1}$ towards the estuary head (Fig. 3a). Nitrate values ranged from 0.9 to $2.1 \mathrm{mg}$-at $\mathrm{N} \mathrm{l}^{-1}$, with the lowest values near the inlet (0.9-1.7 mg-at $\mathrm{N}^{-1}$ ) (Fig. 3b). Nitrite levels varied from 0.3 to $0.6 \mathrm{mg}$-at $\mathrm{N}^{-1}$, with the highest values in the central estuary (Fig. 3c). Phosphate concentrations followed a similar gradient, with high levels $\left(5.2 \mu \mathrm{g}\right.$-at $\left.\mathrm{P}^{-1}\right)$ in the estuary interior and low levels near El Pujo (Fig. 3d). Silicates concentrations exhibited an inverse gradient with high values near El Pujo and decreasing values towards the inlet (Fig. 3e).

The estuary largely contains fine sands, although a mixture of sandy clay mud sediments with mollusk shell remains exists in some zones. Sands were more frequent in the El Pujo area and occurred in a nodule in the inlet (Fig. 4a). High clay values were recorded in El Pujo and decreased towards the inlet (Fig. 4b), while mud content was higher near the inlet and decreased towards El Pujo (Fig. 4c). Sandy sediment was found in the estuary inlet with a slight tendency to larger grain size nearer the coast. In contrast, inside the estuary muds of differing degrees of mixture were more common. High sand content muds were found near the inlet (station 10 had the highest sand proportion). Grain diameter was smallest in the clay mud sediments of the extreme northeast estuary. Clay mud was much more common on the banks while mud or sandy mud sediments were common in the navigation channel. The unconsolidated sediment layer in the channel was very thin with calcareous bedrock essentially at the surface. 


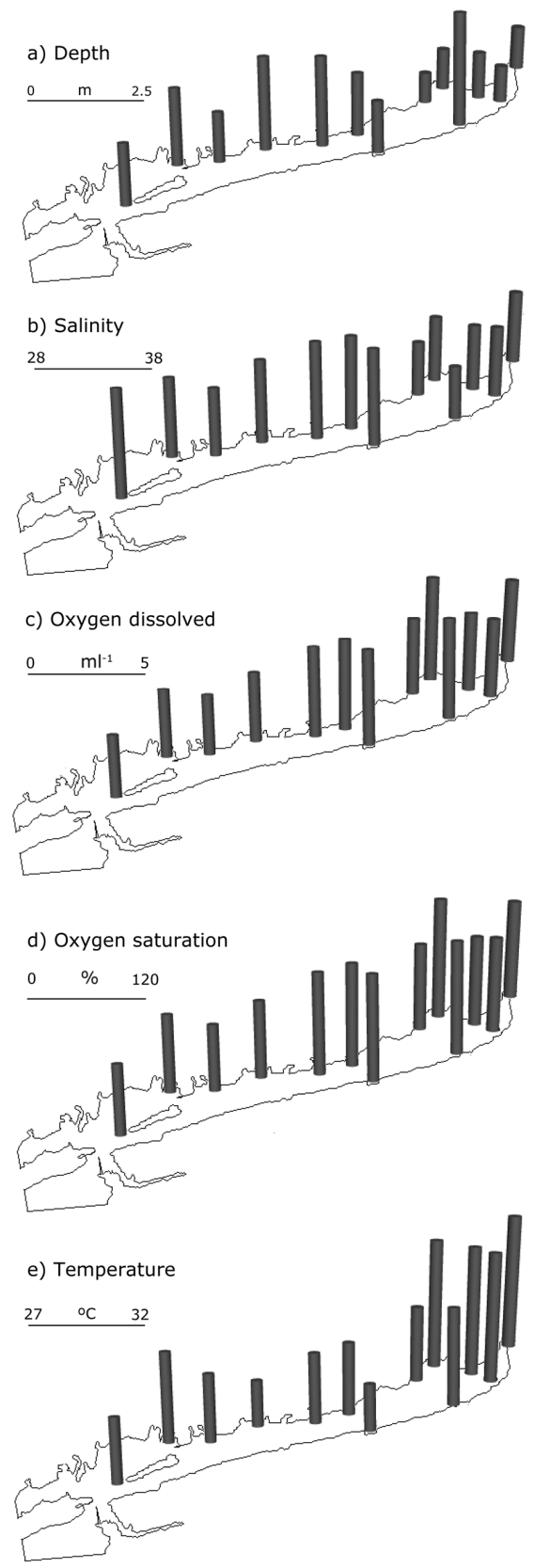

Figure 2. Distribution of principal environmental factors in the Sabancuy Estuary: a) depth; b) salinity; c) oxygen; d) oxygen saturation; and e) temperature. Overall depth, oxygen, oxygen saturation and temperature patterns varied minimally, with high values in the central area and/or adjacent the bridge. Salinity values were highest at the edge of the tideland near its connection to Terminos Lagoon / Distribución de los principales factores ambientales en el estuario de Sabancuy. a) profundidad, b) salinidad, c) oxígeno, d) saturación de oxígeno, e) temperatura. Los patrones que muestran las figuras de profundidad, oxígeno, saturación de oxígeno y temperatura son similares, todos ellos tienen altos valores en la parte media y en la parte adyacente al puente; la salinidad tiene altos valores en las tierras bajas cercanas a su conexión con la Laguna de Términos

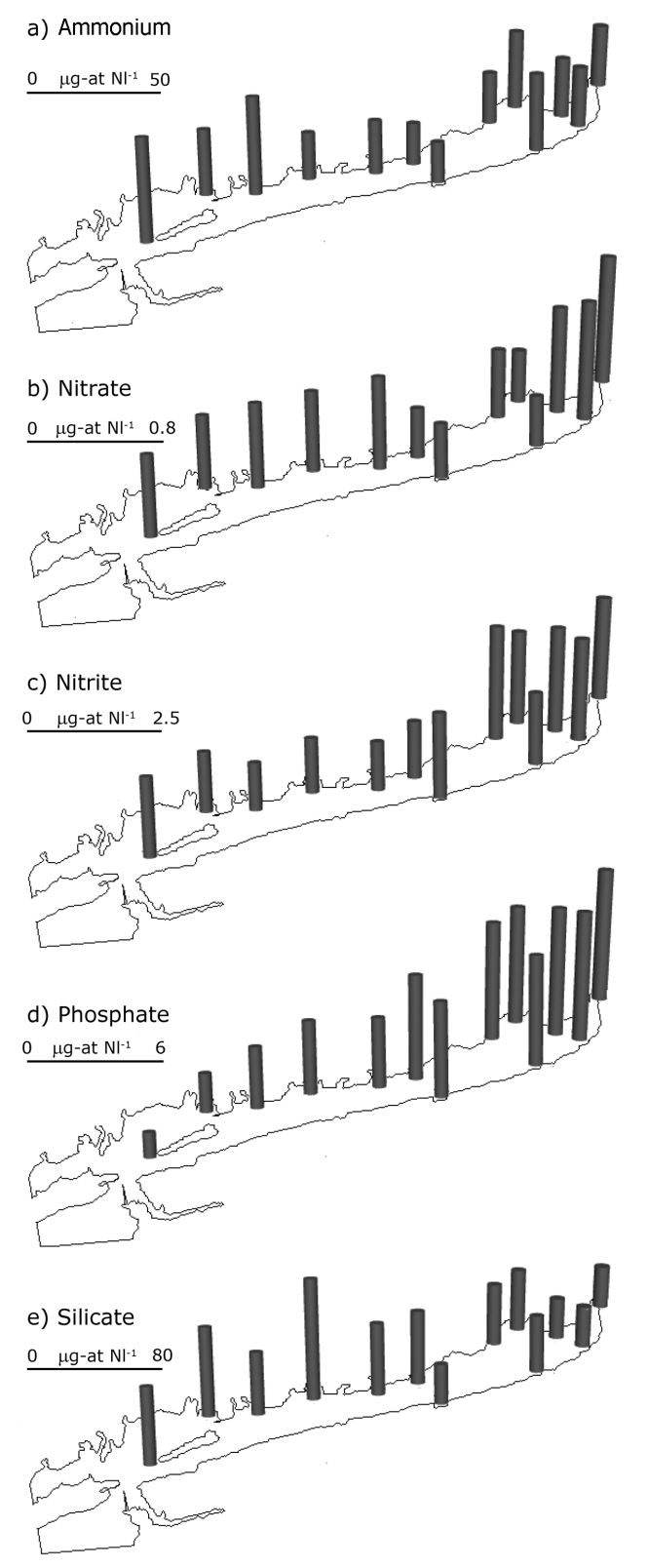

Figure 3. Nutrient distribution in Sabancuy Estuary: a) ammonium; b) nitrate; c) nitrite; d) phosphate; and e) silicate. Nitrate, nitrite and phosphates had high values near the estuary head, close to the sea inlet, as well as at the beginning of the estuary. Ammonium and silicate values were highest in the central portion / Distribución de nutrimentos en el estuario de Sabancuy. a) amonio, b) nitrato, c) nitrito, d) fosfato, e) silicato. Los patrones muestran que el nitrato, nitrito y fosfato tienen altos valores en la cabecera del estuario, cerca de su conexión con el mar y tienen también valores importantes al inicio del estuario. El amonio y silicatos, sus valores principales están en la parte media del estuario 
a) Clay Mud Sand

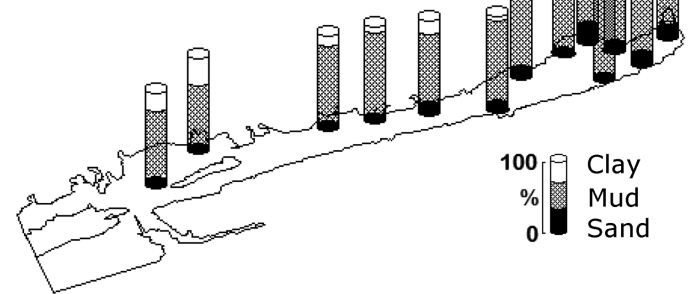

b) Organic matter

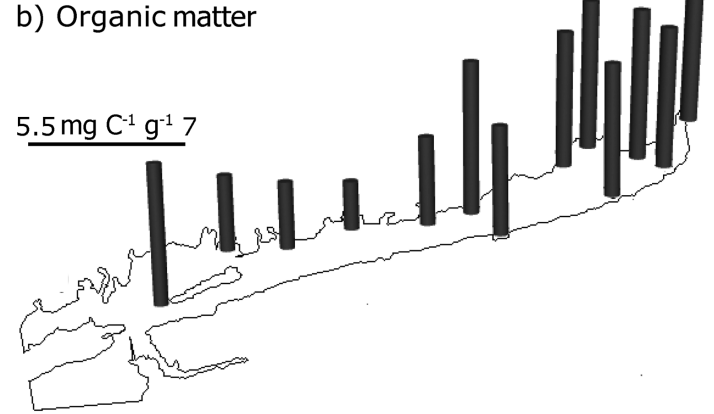

Figure 4. Granulometric components and organic matter in Sabancuy estuary: a) clay, mud and sand; b) organic matter. The patterns for sand, clay and mud differ in that clay had high values at the beginning of the estuary, and sand and organic matter had high values in the estuary head. The mud proportion was very high at all stations / Distribución de los componentes granulométricos y materia orgánica en el estuario de Sabancuy: a) arcilla, limo y arena, b) materia orgánica. Los patrones granulométricos son diferentes, la arcilla tiene altos valores al inicio del estuario, mientras la arena y la materia orgánica tienen altos valores en la cabeza del estuario. No obstante, la proporción de limo es muy alta en todas las estaciones

Sediment organic matter levels were near $7 \mathrm{mg} \mathrm{C}^{-1} \mathrm{~g}^{-1}$ throughout the estuary. The highest values were in the northeast estuary, in conjunction with clay mud sediments, although high values were also recorded at stations near the inlet, despite high sand content. The navigation channels and southwest estuary had values near $6 \mathrm{mg} \mathrm{C}^{-1} \mathrm{~g}^{-1}$ (Fig. 4d). The statistics of environmental variables and water quality are summarized in Table 1 .

The collected Sabancuy Estuary ichthyofauna consisted of 1379 specimens (39 992.8 g cumulative weight) distributed in 33 species (Table 2). Tetrodontidae and Sparidae were the most frequent families and contributed the greatest biomass. The remaining species were quantified using abundance and mean biomass, or sporadic presence for very infrequent species. Abundance and biomass distribution were higher in the central estuary and near the inlet (Figs. 5a and 5b).
Table 1. Environmental variable and water quality data from 13 sites in Sabancuy Estuary, Campeche, Mexico. (SD: standard deviation, min: minimum, max: maximum) / Datos de las variables ambientales y calidad del agua registrados en 13 sitios a lo largo del estuario de Sabancuy, Campeche. (SD: desviación estándar, min: valor mínimo, max: valor máximo)

\begin{tabular}{lrccc}
\hline & Mean & SD & $\min$ & $\max$ \\
\hline Environmental variables & & & & \\
$\quad$ Depht $(\mathrm{m})$ & 1.47 & 0.88 & 0.6 & 2.3 \\
Temperature $\left({ }^{\circ} \mathrm{C}\right)$ & 30.57 & 1.07 & 29 & 32 \\
Salinity & 34.67 & 1.86 & 32.3 & 38.1 \\
Oxygen $\left(\mathrm{ml} \cdot \mathrm{l}^{-1}\right)$ & 3.97 & 0.60 & 3.1 & 4.8 \\
Oxygen Saturation $(\%)$ & 92.53 & 13.95 & 69.7 & 112.3 \\
Sand $(\%)$ & 9.36 & 23.15 & 1 & 91 \\
Mud $(\%)$ & 77.36 & 21.69 & 7 & 94 \\
Clay $(\%)$ & 13.29 & 8.66 & 2 & 33 \\
Organic matter $\left(\mathrm{mg} \mathrm{C}^{-1} \mathrm{~g}^{-1}\right)$ & 6.44 & 0.89 & 3.5 & 7 \\
Water quality & & & & \\
Nitrate $\left(\mu \mathrm{g}\right.$-at $\left.\mathrm{N} \cdot \mathrm{l}^{-1}\right)$ & 1.41 & 0.40 & 0.9 & 2.1 \\
Nitrite $\left(\mu \mathrm{g}\right.$-at $\left.\mathrm{N} \cdot \mathrm{l}^{-1}\right)$ & 0.45 & 0.11 & 0.29 & 0.63 \\
Amonium $\left(\mu \mathrm{g}\right.$-at $\left.\mathrm{N} \cdot \mathrm{l}^{-1}\right)$ & 23.00 & 7.50 & 14.9 & 40.5 \\
Phosphate $\left(\mu \mathrm{g}\right.$-at $\left.\mathrm{P} \cdot \mathrm{l}^{-1}\right)$ & 3.86 & 1.29 & 1.2 & 5.2 \\
Silicate $\left(\mu \mathrm{g}\right.$-at Si $\left.\cdot \mathrm{l}^{-1}\right)$ & 35.53 & 15.40 & 11.6 & 71.5 \\
Community parameters & & & & \\
Biomass $(\mathrm{g})$ & $3,076.37$ & $2,341.94$ & 120 & 6462 \\
Abundance $\left(\mathrm{N}^{\circ}\right.$ ind.) & 106.54 & 89.33 & 8 & 320 \\
Richness $\left(\mathrm{N}^{\circ}\right.$ species) & 12 & 7 & 2 & 33 \\
\hline
\end{tabular}

Spheroides testudinus and Archosargus rhomboidalis were the dominant species, accounting for $38.92 \%$ of total dominance for this group (Table 2). Species richness was highest in the middle of the estuary and poorest in the northeast near the bridge (Fig. 5c). The highest Simpson diversity index values were recorded in the center and the Santa Rosalia area, while the lowest values were near the bridge (Fig. 5d). Evenness was similar to diversity, though it exhibited a nodule of high values in the lagoon's center. It was also higher along the northern estuary edge than on the southern edge (Fig. 5e).

Cluster analysis of fish species abundance produced 3 groupings. The first included most of the stations in the southwest estuary with the closest relationships between stations 2 and 3 . The second showed a close link between stations in the estuary center, and the third a close association between stations 7 and 8 near the bridge (Fig. 6a). Biomass values formed two groups, the first defined by a close relationship between stations 2 and 3 , but including most stations, and the second defined by a close link between stations 7 and 8 (Fig. 6b). 


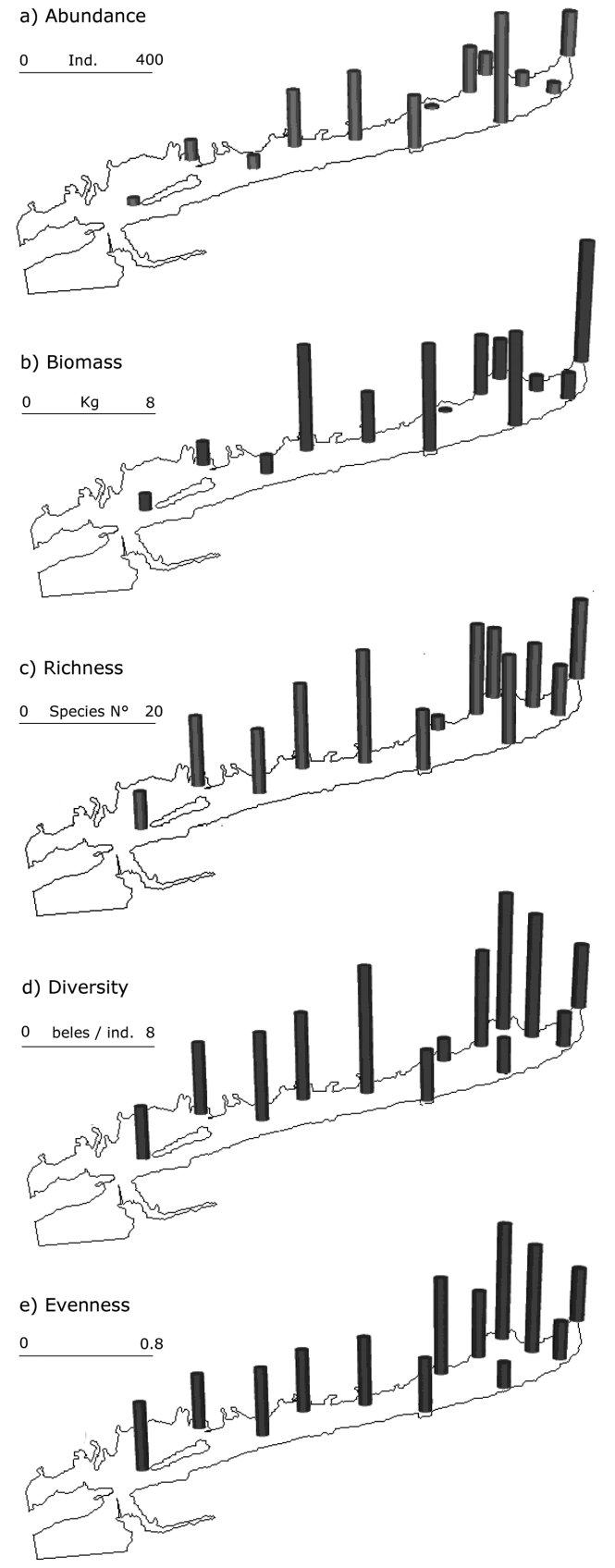

Figure 5. Community descriptors in Sabancuy Estuary; a) abundance; b) biomass; c) richness; d) Simpson's diversity index; and e) evenness. All descriptor patterns were similar, with high values in the central portion and increasingly lower values nearer the beginning of the estuary. Some components had high values near the bridge / Distribución de los descriptores comunitarios en el estuario de Sabancuy, a) abundancia, b) biomasa, c) riqueza de especies, d) índice de Simpson, e) equitatividad. Todos los descriptores comunitarios describen patrones similares, altos valores en la parte media que decaen hacia el inicio del estuario. Algunos componentes muestran altos valores cerca del puente
Table 2. Fish density and dominance (IVI) in the Sabancuy Estuary, Campeche / Densidad de peces y dominancia (IVI) en el estuario de Sabancuy, Campeche

\begin{tabular}{|c|c|c|c|c|}
\hline & Species & $\begin{array}{c}\mathrm{N}^{\mathrm{o}} \\
\text { Ind/trawl }\end{array}$ & (g/trawl) & $\begin{array}{c}\text { Dominance } \\
(\%)\end{array}$ \\
\hline 1 & Achirus lineatus & 17 & 179.4 & 1.576 \\
\hline 2 & Albula vulpes & 1 & 21 & 0.296 \\
\hline 3 & Archosargus probatocephalus & 6 & 127 & 1.014 \\
\hline 4 & Archosargus rhomboidalis & 292 & 5549 & 13.943 \\
\hline 5 & Ariopsis felis & 3 & 350 & 0.618 \\
\hline 6 & Bairdiella batabana & 7 & 367 & 0.729 \\
\hline 7 & Bairdiella chrysoura & 20 & 307 & 2.009 \\
\hline 8 & Bairdiella ronchus & 1 & 18 & 0.294 \\
\hline 9 & Centropomus undecimalis & 27 & 1764 & 3.028 \\
\hline 10 & Cichlasoma uropthalmus & 27 & 609 & 2.430 \\
\hline 11 & Ciprinodon variegatus & 7 & 3 & 0.425 \\
\hline 12 & Citharichthys spilopterus & 2 & 38 & 0.589 \\
\hline 13 & Cynoscion nebulosus & 17 & 490 & 1.835 \\
\hline 14 & Diapterus olisthostomus & 13 & 308 & 2.096 \\
\hline 15 & Diapterus rhombeus & 19 & 354 & 2.279 \\
\hline 16 & Eucinostomus argenteus & 125 & 822 & 6.238 \\
\hline 17 & Eucinostomus gula & 158 & 1308 & 7.183 \\
\hline 18 & Eugerres plumieri & 56 & 1258 & 3.923 \\
\hline 19 & Floridicthys carpio & 40 & 188 & 2.137 \\
\hline 20 & Gerres cinereus & 5 & 157 & 1.015 \\
\hline 21 & Harengula jaguana & 56 & 792 & 2.517 \\
\hline 22 & Lutjanus analis & 2 & 37 & 0.333 \\
\hline 23 & Lutjanus griseus & 16 & 984 & 2.223 \\
\hline 24 & Mugil cephalus & 41 & 2066 & 3.472 \\
\hline 25 & Oligoplistes saurus & 3 & 94 & 0.659 \\
\hline 26 & Opsanus beta & 6 & 658 & 1.711 \\
\hline 27 & Orthopristis chrysoptera & 89 & 1150 & 3.609 \\
\hline 28 & Poecilia latipinna & 5 & 28 & 0.398 \\
\hline 29 & Prionotus carolinus & 1 & 102 & 0.364 \\
\hline 30 & Spheroides testudineus & 283 & 17830 & 24.98 \\
\hline 31 & Strongilura timuсu & 17 & 1120 & 3.378 \\
\hline 32 & Sygnatus scovelli & 1 & 17.4 & 0.279 \\
\hline 33 & Synodus foetens & 16 & 914 & 2.419 \\
\hline
\end{tabular}

The canonical analysis indicated phosphate to strongly affect fish abundance, and other variables such as organic matter and mud affected site and species spatial organization. Depth and salinity had the greatest effect on biomass spatial organization (Fig. 7).

\section{Discussion}

Phosphates can be a limiting factor, but this system has high values. The high concentrations recorded in the estuary interior and at the inlet may be caused by the large quantities of domestic detergents dumped into the system via urban drainage systems (Piet 1996, Mortazavi et al. 2000), probably from the town of Sabancuy. Another significant source of phosphates may be chemical fertilizers 


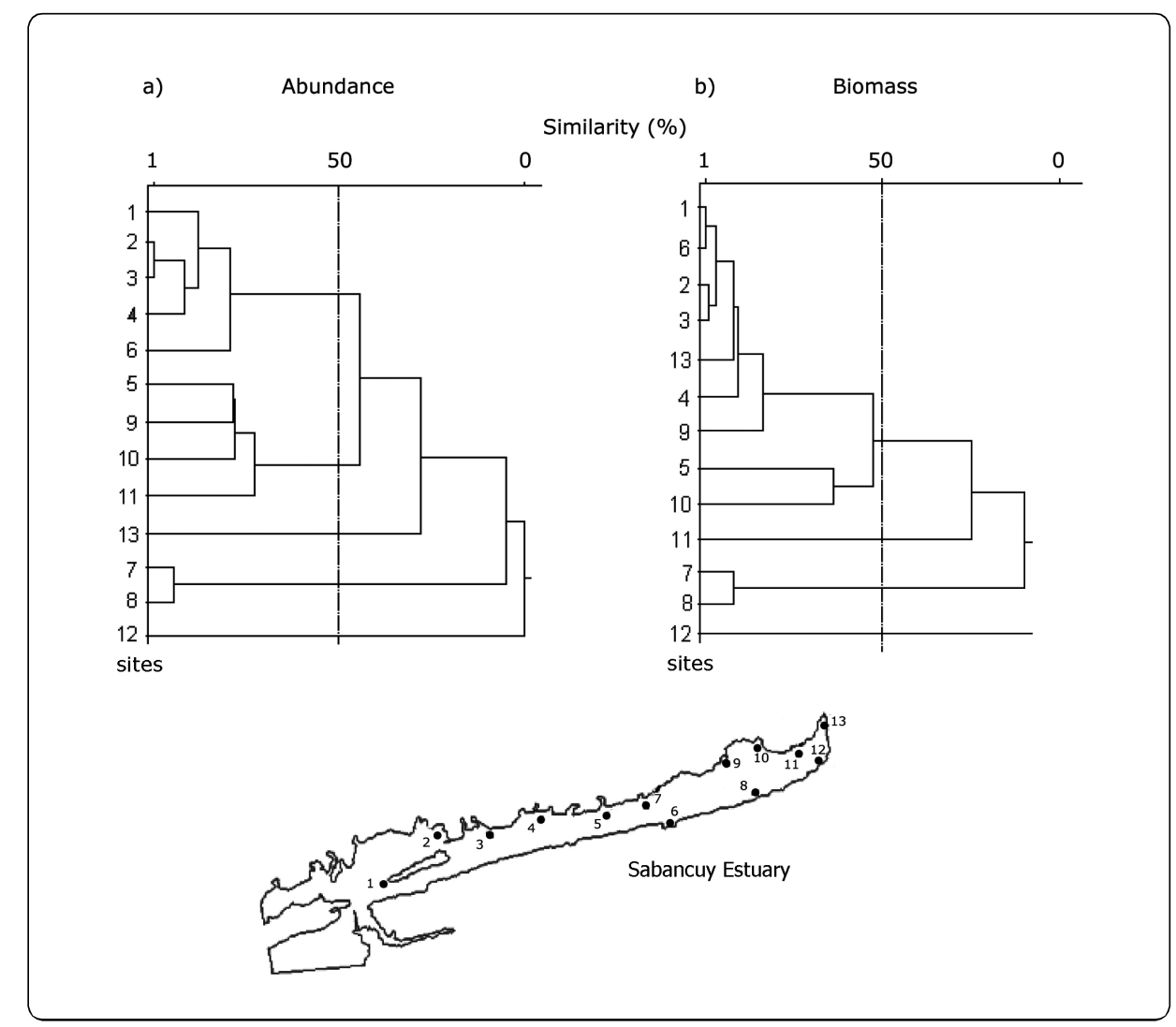

Figure 6. Dendrogram produced using the Morisita index representing sites clusters based on fish abundance (a) and biomass (b) data of Sabancuy Estuary. A map of the sampling stations is included for comparison / Dendrograma obtenido con el índice de Morisita que representa el ensamblaje de estaciones con datos de abundancia (a) y biomasa (b) de los peces del estuario de Sabancuy. Las figuras muestran el ensamblaje de los sitios en el estuario. También se muestra un mapa con los sitios de muestreo

used on commercial crops in the region. This increases primary production and is consequently an important factor determining fish abundance and biomass. Overall, the nitrogen and phosphate concentrations in Sabancuy estuary were sufficient to support a total system productivity of approximately $650 \mathrm{mg} \mathrm{C}^{-\mathrm{m} 3} \mathrm{~d}^{-1}$.

High oxygen oversaturation values are an indicator of high photosynthetic activity. In Sabancuy, the lowest value was $70 \%$, meaning the system had no oxygen deficit. These values are within the ranges recorded by Villalobos \& Zamora (1975) in Campeche Sound. The fact that Sabancuy Estuary has such high oxygen values is likely due to a dynamic caused by winds and shallow water (Armstrong 1997).
The recorded nitrogen (nitrites and nitrates) concentrations are not limiting or toxic for plankton development. Only in the central estuary did concentrations drop in response to homogeneity in phytobenthos photosynthetic activity. Ammonia levels exhibited a gradient produced by organic matter remineralization since this is easily assimilated by primary producers. The lowest concentration, recorded in the area near the bridge, may indicate an increase in the production rate (Bravo \& Yáñez-Arancibia 1979, Yáñez-Arancibia et al. 1988, Dudley et al. 2001).

Silicates have a slower cycle than nitrogen and phosphates, and their accumulation near El Pujo may result from the low circulation rates near the urban area. In the rest of the system, silicates are moved towards the 


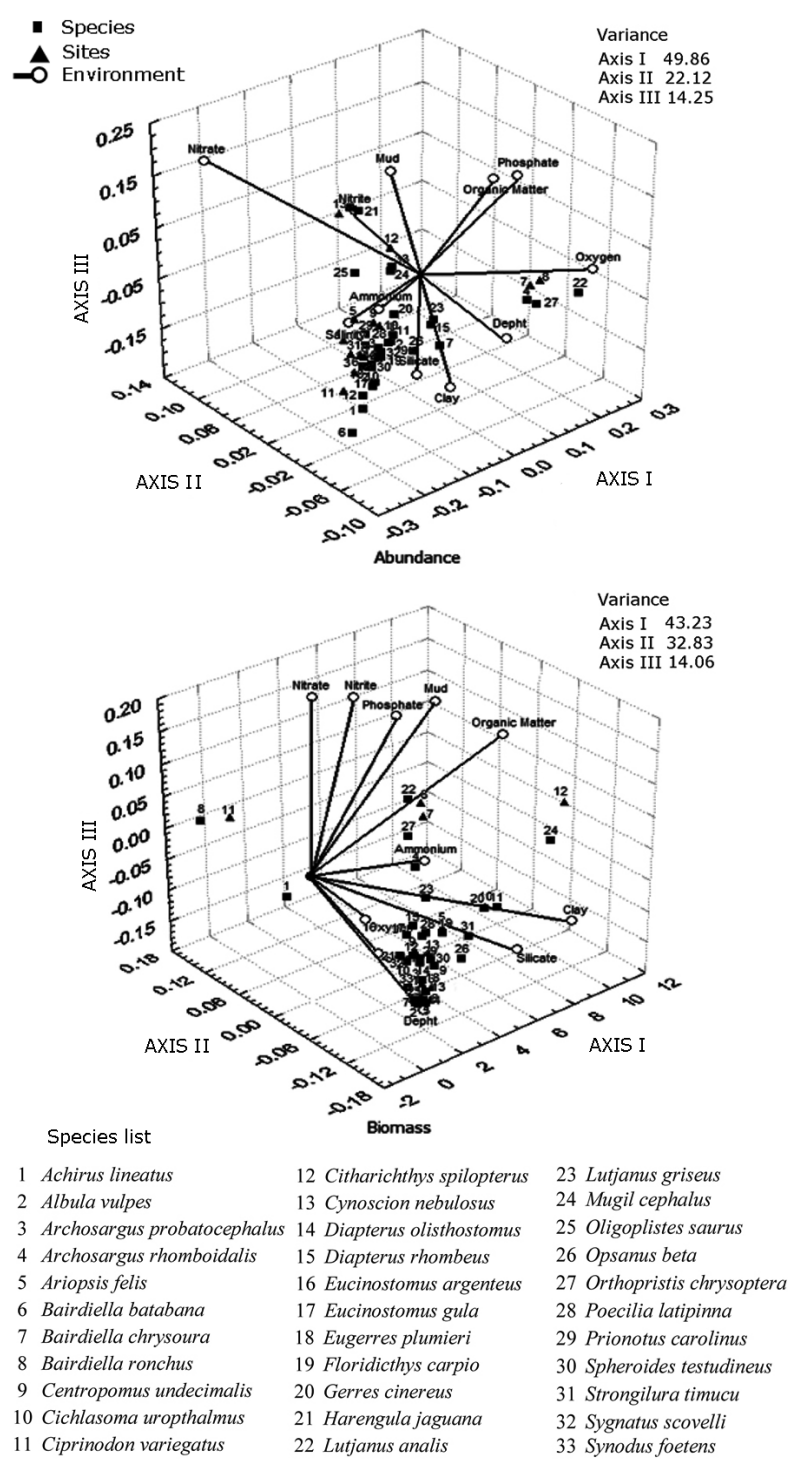

Figure 7. Species-conditional triplot based on a canonical correspondence analysis of fish species data showing the variance explained by each axis. The abundance eigenvalue for axis 1 (horizontal) is 0.629 , for axis 2 (vertical) is 0.454 and for the axis 3 is 0.411 . The biomass eigenvalue for axis 1 is 0.577 , for axis 2 is 0.529 and for axis 3 is 0.468 . Sampling stations (triangles) and species (squares) are numbered, while environmental variables are indicated by arrows / Triplot de la condición de las especies basadas en un análisis de correspondencia canónica de las especies de peces que muestran la varianza explicada por cada eje. Los eigenvalores del eje 1 (horizontal) de la abundancia es 0,629 , el eje 2 (vertical) es 0,454 y para el eje 3 es 0,411 . Los eigenvalores de eje I de la biomasa es 0,577, para el eje 2 es 0,529 y 0,468 para el eje 3 respectivamente. Los sitios (triángulos) están etiquetados con números. Las especies (cuadrados) están también etiquetadas con números, y las variables ambientales están indicadas con flechas ocean by tidal currents (Suarez \& Gómez 1965, Gido \& Mathews 2000), resulting in an imbalance expressed as a negative influence on population density in the fish community.

The sandy sediments near the sea inlet were probably associated with turbulence in water masses, and their extension into the lagoon may be due to both eolic transport and tidal currents. Mud and badly sorted mixed sediments ( 1 to $2 \phi$ diameter) were widely distributed on the lagoon floor, especially on the side parallel its continental bank. These sediments may have been deposited by surface runoff and coastal erosion. Sabancuy Estuary is completely surrounded by mangrove, and organic matter content is closely linked to contributions from this vegetation. No substantial organic matter contribution or transport occurs in the southwest portion of the estuary due to very low tidal flow influence.

Diversity is low near El Pujo and increases towards San Nicolas after which it begins to decrease until reaching its lowest levels near the bridge. Once past the bridge it again increases, reaching its highest levels in the widest portion of the estuary, but falls noticeably in its narrower branches. This latter reduction in diversity is natural and in direct relation to water surface area (Swartz et al. 1986). The reduction near the bridge, however, is more likely due to the physical barrier it represents in the estuarine complex, which causes environmental instability. Evenness values in this study are considered an indicator of resource availability and use. Based on the present data, there is more resource availability along the north estuary edge, or conditions there prevent any one species from dominating the community.

Biological characteristics in Sabancuy Estuary are very heterogeneous. This conclusion is based on the criteria used in determining station association, which included density values (number and biomass), specific richness and the presence or absence of recorded elements. System heterogeneity is manifest most clearly in the northeast estuary, and is slightly more homogeneous in the southwest. In fact, stations were identified that associated with other stations because of component presence and density, but were actually juvenile growth areas (Díaz-Ruiz et al. 2003, Rodríguez-Romero et al. 2011). For instance, stations 8 and 9, in the inlet near the ocean, both had adequate habitats for Orthopristis chrysoptera growth, and station 8 was particularly good for Archosargus romboidalis growth. Stations at the estuary head had excellent conditions for Harengula jaguana 
growth (Felley \& Felley 1986), and the northeast portion had good conditions for Eucinostomus gula, near station 5. Spheroides testudineus exhibited a preference for the zone around station 6, though it was found throughout the system. This species was also recorded in larger sizes in the northeast estuary, indicating that it may use the two sections of the estuary differentially in its growth cycle (Yañez-Arancibia \& Nugent 1978).

Stations in the southwest zone (El Pujo) and adjacent the inlet were isolated from the other station groups, indicating there to be a stress gradient clearly separating these areas. The influence controlling these factors is less evident in the other groups, leading to separation of the main group. This implies that these elements respond differently to the gradient imposed by ecological controllers in this zone (Kupshus \& Tremain 2001, Vasconcellos et al. 2010). Analysis of estuary system physical and chemical factors suggests the main cause of this gradient to be phosphate distribution. If this is the case, phosphate concentrations may be responsible for the abundance and biomass spatial patterns observed in Sabancuy Estuary. This is contrary to previous reports for tropical estuaries in which salinity is the main controlling factor for estuarine fauna abundance and biomass (Díaz-Ruíz et al. 2004, Velázquez-Velázquez et al. 2008). This apparently does not hold true for Sabancuy Estuary, even though it has a slightly hyperhaline behavior.

\section{General CONSIDERATIONS}

The Sabancuy Estuary fish community has significant species assemblages that do not support the possibility of an independent fauna distribution for each sampled location. Location groupings were determined by similar or antagonist resources use requirements (space, habitat and food), implying that the presence of one species conditions the presence or absence of another. Marine component eurihaline species and estuarine component seasonal species dominated the estuary, while the freshwater component was represented only by Cichlasoma uropthalmus and Poecilia latipina.

Among the most important results are the high level of interactions between stations and the high correspondence between biomass and density (Whitfield 1993). Due to estuary conditions, oxygen and phosphorous exchange rates between the water column and sediments are very strong in the northern portion where it communicates with the ocean, probably because of tidal currents. Fauna density is determined by a complex of variables in which most of the explained variation would be accounted for by phosphates concentrations. These would account for more variation than salinity, as shown by the multiple correlation coefficients. Nutrient flow in sediments may also play a significant role in material recycling in this shallow system, with constant phosphate contribution from nearby human populations (Sundareshwar et al. 2001). Another factor in the estuary dynamic is that invertebrate fragments in the estuary, probably an input from wave action, also enrich the detritus and constitute an important link in the food chain.

Arche (2010) mentions that sediments represent a storage medium for materials formed in the water column and that fractions of these will return to the water column via the macro- and microbenthos responsible for recycling. The effective sediment movement in Sabancuy Estuary is a result of the system's shallowness and the wind and tidal current forces that dominate the estuary.

The ecological organizational scheme in the system suggests that the estuary is divided into two sections, separated by the bridge. Species are poor at the two extremes of the lagoon. On the El Pujo side, this is caused by a shallow water column and minimal communication with Terminos Lagoon. On the inlet side, it is largely due to the estuary's narrow topography, which restricts water circulation in this zone, despite tidal influence. Both factors contribute to the same result: scarcity of habitat and food resources (Wagner \& Austin 1999; Kenouse et al. 2006; Ribeiro et al. 2006).

Some authors (Yañez-Arancibia et al. 1994, Blaber 1997, Castillo-Rivera 2001, Barreiros et al. 2009) have mentioned competition and predation as biologically important interactions in species overlap and resource use in the tropics. In this scenario, species survival and persistence are the result of resource diversity, spatial heterogeneity in microhabitats and high productivity, which generate complex relationships between organisms in these regions. For the Sabancuy Estuary fish community, however, environmental elements are the main controllers. Phosphates are especially important in fish community structure as more than $50 \%$ of the species (in abundance or biomass) responded directly to this element and not to salinity, as has been reported previously. The activity of other factors such as productivity, decomposition, element recirculation in contributing systems, etc. require further study to understand and evaluate organic yield potential, the natural capacity for waste processing and degradation 
process alternatives (Wilbur \& Tiller 1970, Sundareshwar et al. 2001, Moyle \& Cech 2004, Hoeksema \& Potter 2006). The present study is an excellent foundation for this future research.

\section{LITERATURE CITED}

Arche A. 2010. Sedimentología: del proceso físico a la cuenca sedimentaria. CSI-UCM, 1288 pp. Facultad de Geología. Universidad Complutense de Madrid, Madrid.

Armstrong MP. 1997. Seasonal and ontogenetic changes in distribution and abundance of smooth flounder, Pleuronectes putnami, and winter flounder, Pleuronectes americanus, along estuarine depth and salinity gradients. Fishery Bulletin 95: 414-430.

Barreiros JP, JO Branco, FF Junior, L Machado, M HostimSilva \& JR Verani. 2009. Space-time distribution of ichthyofauna from Saco da Fazenda estuary, Itajaí, Santa Catarina, Brazil. Journal of Coastal Research 25(5): 11141121.

Bravo NE \& A Yañez-Arancibia. 1979. Ecología de la Boca de Puerto Real Laguna de Términos, Campeche. Anales del Centro de Ciencias del Mar y Limnología, UNAM 7(1): 69118.

CarranzaEdwards A, M Gutierrez \& R Rodriguez. 1975. Unidades morfotectónicas continentales de las costas mexicanas. Anales del Centro de Ciencias del Mar y Limnología, UNAM 2(1): 8188.

Castillo-Rivera M. 2001. Biología trófica de especies de peces dominantes en ecosistemas estuarinos del Golfo de México. Tesis de Doctorado en Ciencias Biológicas, Universidad Autónoma Metropolitana, México, 192 pp.

Contreras F. 1993. Ecosistemas costeros mexicanos, 415 pp. Ed. UNAM, México.

Day JW, RH Day, M Barreiro, F LeLou \& C Madden. 1982. Primary production in the Laguna de Términos, a tropical estuary in the southern Gulf of Mexico. Proceedings of International Symposium on Coastal Lagoons. ISCOL UNESCO, Burdeaux, France. Oceanológica Acta 5(4): 269 276.

Díaz-Ruíz S, MA Pérez-Hernández \& A Aguirre-León. 2003. Characterization of fish assemblages in a tropical coastal lagoon in the northwest Gulf of Mexico. Ciencias Marinas 29: 631-644.

Díaz-Ruíz S, E Cano-Quiroga, A Aguirre-León \& R OrtegaBernal. 2004. Diversidad, abundancia y conjuntos ictiofaunísticos del sistema lagunar-estuarino ChantutoPanzacola, Chiapas, México. Revista de Biología Tropical 52(1): 187-199.

Dudley BJ, AME Gahnström \& DI Walter. 2001. The role of benthic vegetation as a sink for elevated inputs of ammonium and nitrate in a mesotrophic estuary. Marine Ecology Progress Series 219: 99-107.
Escanero FG. 1983. Ciclo hidrográfico anual (Marzo, 1981 Abril 1982) de la laguna de Términos, Campeche. Tesis Licenciatura en Oceanografía, CICESE, Ensenada, México, $92 \mathrm{pp}$.

Felley JD \& SM Felley. 1986. Habitat partitioning of fishes in an urban, Estuarine Bayou. Estuaries 9(3): 208-218.

Galluci VF. 1973. On the principles of thermodynamics in ecology. Annual Review of Ecology and Systematic 4: 329. 357.

Gido KB \& WJ Mathews. 2000. Dynamics of the offshore fish assemblage in a Southwestern reservoir (Lake Texoma, Oklahoma-Texas). Copeia 4: 917-930.

Graham DS, JP Daniels, JM Hill \& JW Day. 1981. A preliminary model of the circulation of Laguna de Términos, Campeche, México. Anales del Centro de Ciencias del Mar y Limnología UNAM 8(1): 5162.

Hoeksema SD \& IC Potter. 2006. Diel, seasonal, regional and annual variations in the characteristicss of the ichthyofauna of the upper reaches of a large Australian microtidal estuary. Estuarine, Coastal and Shelf Science 67: 503-520.

Kenouse S, MK LaPeyre \& JA Nyman. 2006. Nekton use of Ruppia maritima and non-vegetated bottom habitat types within brackish marsh ponds. Marine Ecology Progress Series 327: 61-69.

Kupshus S \& D Tremain. 2001. Association between fish assemblages and environmental factors in nearshore habitats of subtropical estuary. Journal of Fish Biology 58(5): 13821403 .

Mancilla M \& M Vargas. 1980. Los primeros estudios sobre la circulación y el flujo neto de aguas a través de la Laguna de Términos, Campeche. Anales del Centro de Ciencias del Mar y Limnología, UNAM 7(2): 112.

Margalef R. 1993. Teoría de los ecosistemas ecológicos, 290 pp. Universitat de Barcelona Publicacions, Barcelona.

Mortazavi B, RL Iverson, WM Landing \& W Huang. 2000. Phosphorous budget of Apalachicola Bay: A river-dominated estuary in the northeastern Gulf of Mexico. Marine Ecology Progress Series 198: 33-42.

Moyle PB \& JJ Cech. 2004. Fishes: An introduction to ichthyology, 726 pp. Prentice-Hall, Upper Saddle River.

Orlóci L. 1978. Multivariate analysis in vegetation research, 97 pp. Dr. W.J.Junk Publishers, The Hage.

Pielou EC. 1984. The interpretation of ecological data: A premier on classification and ordination, $235 \mathrm{pp}$. Wiley Interscience, New York.

Piet GJ. 1996. Impact of environmental perturbation on a tropical fish community. Canadian Journal Fisheries of Aquatic Science 55: 1842-1853.

Pollard DA. 1994. A comparison of fish assemblages and fisheries in intermittently open and permanently open coastal lagoons on the south coast of New South Wales, south-eastern Australia. Estuaries 17: 631-646. 
Ribeiro J, L Bentes, R Coelho, JMS Goncalves, PG Lino, P Monteiro \& K Erzini. 2006. Seasonal, tidal and diurnal changes in fish assemblages in the Ria Formosa Lagoon (Portugal). Estuarine, Coastal and Shelf Science 67: 461474.

Rodríguez-Romero J, LC López-González, F GalvánMagaña, FJ Sánchez-Gutiérrez, R Inohuye-Rivera R \& JC Pérez-Urbiola. 2011. Seasonal changes associated with mangroves in a coastal lagoon of Baja California Sur, México. Latin American Journal of Aquatic Research 39(2): 250-260.

Strickland JDH \& TR Parsons. 1972. A practical handbook of sea water analysis. Fisheries Research Board of Canada Bulletin 167: 1-310.

Suarez CJ \& S Gómez. 1965. Observaciones sobre el plancton de la Laguna de Términos, Campeche, México. Bulletin of Marine Science 15(4): 10721120.

Sundareshwar PV, JT Morris, PJ Pellechia, KJ Cohen, DE Porter \& BC Jones. 2001. Occurrence and ecological implications of pyrophosphate in estuaries. Estuaries 213: 1570-1577.

Swartz RC, FA Cole, DW Schultz \& WA Deben. 1986. Ecological changes in the Southern California Bight near a large sewage outfall: benthic conditions in 1980-1983. Marine Ecology Progress Series 31: 113.

Vasconcellos RM, FG Araújo, JNS Santos \& MA Silva. 2010. Short term dynamics in fish assemblage structure on a sheltered sandy beach in Guanabara Bay, Southeastern Brazil. Marine Ecology 31: 506-519.

Velázquez-Velázquez E, ME Vega-Cendejas \& J NavarroAlberto. 2008. Spatial and temporal variation of fish assemblages in a coastal lagoon of the biosphere reserve $\mathrm{La}$ Encrucijada, Chiapas, México. Revista de Biología Tropical 56(2): 557-574.
Villalobos AF \& ME Zamora. 1975. Importancia biológica la Bahía de Campeche de la Península de Yucatán. II Simposium Latinoamericano de Oceanografía Biológica. San José, Venezuela, pp. 47-62.

Vitousek PM, HA Mooney, J Lubchenco \& JM Melillo. 1997. Human domination of Earth's Ecosystems. Science 277: 494-499.

Wagner ICM \& HM Austin. 1999. Correspondence between environmental gradients and summer littoral fish assemblages in low salinity reaches of the Chesapeake Bay, USA. Marine Ecology Progress Series 177: 197-212.

Whitfield AK. 1993. Fish biomass estimates from the littoral zone of an estuarine coastal lake. Estuaries 16: 280-289.

Wilbur L \& J Tiller. 1970. Man and environment change in South America. BioScience 32: 1040-1042.

Yañez-Arancibia A \& RS Nugent. 1978. El papel ecológico de los peces en estuarios y lagunas costeras. Anales del Centro de Ciencias del Mar y Limnología UNAM 4(1): 107-114.

Yáñez-Arancibia A, A Lara-Dominguez, JL Rojas-Galaviz, P Sánchez-Gil, JW Day \& CJ Madden. 1988. Seasonal biomass and diversity of estuarine fishes coupled with tropical hábitat heterogeneity (southern Gulf of Mexico). Journal of Fish Biology 33: 191-200.

Yañez-Arancibia A, A Lara-Dominguez \& D Pauly. 1994. Coastal lagoons as fish habitats. In: Kjerfve B (ed). Coastal lagoon processes. Elsevier Oceanography Series 60: 363 376. Elsevier Science Publisher, Amsterdam. 